\title{
Characterisation of a novel vaccine delivery system for livestock
}

\author{
Rebecca K. McLean ${ }^{1,2^{*}}$, Ann R. Wood ${ }^{1}$, Jayne C. Hope ${ }^{2}$, Gary Entrican', David J. Griffiths ${ }^{1}$ \\ From 1st Annual Meeting of the Scottish Society of Cytomics (SCC) 2014. "Translational Cytometry from \\ Bench to Bedside" \\ Aberdeen, UK. 25 September 2014
}

\section{Background}

Healthy animals perform better than those that are diseased; therefore there are significant benefits from preventing disease on farm by investigating new vaccine delivery systems. Recently, viral vectors have risen to prominence as candidates for generating immune responses. Of these viral candidates, lentiviruses are attractive as they have the ability to transduce nondividing antigen presenting cells. For example, lentiviral vectors have been shown to produce an antigenmediated immune response in mice, providing long term, sterile protection against Malaria[1].

\section{Material and methods}

Transformed human embryonic kidney (293T) cells were transfected with four plasmids which encode the various vector components for the production of lentiviral vectors. Vectors produced so far contain an eGFP reporter cassette to facilitate measurement of infectivity by flow cytometry. Self-inactivating (SIN) vectors have been produced to decrease the probability of the generation of replicationcompetent virus[2]. To produce a SIN vector, viral enhancers and promoter sequences were deleted by Gibson Cloning leaving expression of transgenes controlled by an internal promoter. Integrase deficient lentiviral vectors were produced by introducing point mutations by PCR on the D,D-35-E motif within the integrase protein to reduce insertional oncogenesis[3].

\section{Results}

Stable expression of antigens is important to a successful vaccine, therefore the stability of ovine lentiviral

\footnotetext{
* Correspondence: Rebecca.McLean@moredun.ac.uk

'Moredun Research Institute, Pentlands Science Park, Edinburgh, EH26 OPZ, UK. *

Full list of author information is available at the end of the article
}

transduction was evaluated over a 4 week period with eGFP-positive cells measured periodically. $50 \%$ of cells remained eGFP-positive after 4 weeks in rapidly dividing cells suggesting a sustained, stable transduction. Ovine lentivirus vectors have the ability to infect a wide range of cell types from different species with similar efficiency to the well characterised murine leukaemia virus (MLV) vector. Self-inactivating vectors with non-active LTRs retain the ability to express transgenes in vitro. Integration deficient vectors appear to have to correct phenotype as eGFP-positive cells decreased over time in dividing cells.

\section{Conclusion}

We have created a novel, self-inactivating, integration deficient ovine lentiviral vector which retains the ability to express transgenes in vitro. Future studies will investigate ovine lentiviral vectors mechanisms of immune response in vitro and study their efficiency to deliver appropriate immunity in vivo.

\section{Acknowledgements}

This project is funded by Moredun Scientific and the Scottish Government.

\section{Authors' details}

${ }^{1}$ Moredun Research Institute, Pentlands Science Park, Edinburgh, EH26 OPZ, UK. * ${ }^{2}$ Royal (Dick) School of Veterinary Science, University of Edinburgh, EH25 9RG, UK.

Published: 16 April 2015

\section{References}

1. Coutant F, David RYS: A nonintegrative lentiviral vector-based vaccine provides long-term sterile protection against Malaria. PLoS One 2012, 7: e48644.

2. Zufferey R, Dull T: Self-inactivating lentivirus vector for safe and efficient in vivo gene delivery. J. Virol 1998, 72:9873-9880.

3. Gaur M, Leavitt AD: Mutations in the human immunodeficiency virus type 1 integrase $D, D(35) E$ motif do not eliminate provirus formation. J. Virol 1998, 72:4678-4685. 
Submit your next manuscript to BioMed Central and take full advantage of:

- Convenient online submission

- Thorough peer review

- No space constraints or color figure charges

- Immediate publication on acceptance

- Inclusion in PubMed, CAS, Scopus and Google Scholar

- Research which is freely available for redistribution 